\title{
Chronic Administration of Sildenafil Citrate (Viagra) on the Frontal Cortex of Adult Male Rats: An Ultrastructural Study
}

\author{
Salama Essam Eldin Abdelhady1,2 \\ ${ }^{1}$ Department of Anatomy and Embryology, Faculty of Medicine, King Saud University, Riyadh, Kingdom of Saudi Arabia \\ ${ }^{2} \mathrm{Al}$ Azhar University, Cairo, Egypt \\ Email: essamco58@gmail.com
}

How to cite this paper: Abdelhady, S.E.E. (2020) Chronic Administration of Sildenafil Citrate (Viagra) on the Frontal Cortex of Adult Male Rats: An Ultrastructural Study. Forensic Medicine and Anatomy Research, 8, 38-44.

https://doi.org/10.4236/fmar.2020.82004

Received: January 19, 2020

Accepted: April 10, 2020

Published: April 13, 2020

Copyright $\odot 2020$ by author(s) and Scientific Research Publishing Inc. This work is licensed under the Creative Commons Attribution International License (CC BY 4.0).

http://creativecommons.org/licenses/by/4.0/

\begin{abstract}
Objectives: Sildenafil citrate (Viagra) is widely used as an aphrodisiac drug and for the treatment of erectile dysfunction. The present study was planned to study the morphological changes that might occur in the frontal cortex of the adult rat in response to chronic intake of Viagra and discover whether these changes are reversible or irreversible. Material and Methods: Forty adult male rats were used where they were classified into three groups: A control group (10 rats), B experimental treated group (20 rats), and $\mathrm{C}$ recovery group (10 rats). The treated and recovery groups received therapeutic dose of Viagra for 30 days. The control and the treated group were sacrificed at the first day after the designated period ( 30 days), the recovery group was sacrificed two weeks after the end of experiment. Results: The pyramidal cell neurons are little in number; some of them are atrophic, degenerated. Their cytoplasm showed varied degree of cellular degenerative changes with vaculation of their myelinated axons. Pyramidal neurons of recovery animals showed nearly complete recovery. Conclusion: Chronic intake of Viagra produced reversible morphological changes in pyramidal neurons of the frontal cortex of adult male rats.
\end{abstract}

\section{Keywords}

Adult Albino Rats, Sildenafil Citrate, Ultra-Structural Findings

\section{Introduction}

The nervous system is a unique target for toxic agents in several ways. The adult neuron does not divide and therefore replacement of the lost cells is not possible. There is barrier to passage of many blood borne substances unless they are monopolar or are actively transported. The normal function of the nervous system 
requires the action of a complex integrated network, so damage to even a small portion of the nervous system sometimes can result in marked effect on function [1].

Sildenafil citrate (Viagra) is highly selective inhibitor of the cyclic guanosine monophosphate (cGMP) degrading intracellular enzyme phosphodiesterase $S$ (PDES) widely used as treatment for erectile dysfunction [2] [3]. (PDES) was present in penile tissue, platelets, skeletal muscles, vascular and visceral smooth muscles, so Sildenafil acted via release of nitric oxide [4]. It also presented in brain tissue and in the superior cervical ganglion [5] [6]. Sildenafil had found effective in several subpopulations of men with erectile dysfunction, including sufferers from diabetes [7], hypertension [8], spinal cord injuries [9] and schizophrenia [10] [11].

Sildenafil was widely used by men aged 40 - 70 years, even with chronic diseases. It was rapidly absorbed after oral administration, with a mean absolute bioavailability of $41 \%$ (range $25 \%$ - 63\%). Maximum observed plasma concentrations were reached within 30 to 120 minutes (median 60 minutes). It was eliminated predominantly by hepatic metabolism, and was converted to an active metabolite with properties similar to the parent, sildenafil. Both sildenafil and the metabolite had terminal half-lives of about 4 hours. Sildenafil was excreted as metabolites predominantly in the feces (approximately $80 \%$ of administered oral dose) and to a lesser extent in the urine (approximately $13 \%$ of the administered oral dose). The most common adverse reactions reported in clinical trials $(\geq 2 \%)$ were headache, flushing, dyspepsia, abnormal vision, nasal congestion, back pain, myalgia, nausea, dizziness, and rash [12].

The present work was therefore designed to determine the effect of chronic administration of sildenafil citrate in therapeutic dose for 30 days on frontal cortex of adult male rats and discover whether these effects are reversible or irreversible.

\section{Material \& Methods}

Forty adult male albino rats, weighing $200-250$ gm were used in the present study. They were divided into three groups; A control group (10 adult male rats) and $\mathrm{B}$ experimentally treated group (20 adult male rats), and $\mathrm{C}$ recovery group (10 adult male rats). Sildenafil citrate $(50 \mathrm{mg}$ tablets) was obtained from Pfizer Company. The adult rats of the experimentally treated and the recovery groups received $0.7 \mathrm{mg} / \mathrm{kg}$ body weight according to Eweka and Eweka [13] it was varied between $(0.140 \mathrm{mg})$ for rats weighing $200 \mathrm{gm}$ to $(0.175 \mathrm{mg})$ for rats weighing $250 \mathrm{gm}$, as a single daily dose, dissolved in distilled water, and given through an oro-gastric feeding tube for 30 days while the control group received equal volume of distilled water daily single dose during the experimental period.

The rats of the control group (A) and the experimentally treated group (B) were sacrificed one day after the designed period. The remaining 10 rats of the recovery group (C) were sacrificed two weeks later. Small pieces of the frontal cortex ( $1 \mathrm{~mm}$ in dimension) were taken and put in $3 \%$ glutaraldehyde for few 
hours. The specimens were processed for transmission electron microscope according to Palay and Chan [14]. Ultra-thin sections were double stained with uranyl acetate and lead citrate, according to Hayat [15] for ultra-structural examination. Then, they were examined and photographed.

\section{Results}

\section{1) Control Group}

\section{Electron Microscopic Findings:}

The ultra thin sections of the frontal cortex of the adult male rats showed that the pyramidal cell neurons had pyramidal shaped nucleus with fine chromatin (i.e. euchromatic nucleus). The nucleus contained dispersed chromatin, with mild aggregation and peripheral chromatin margination. The cytoplasm surrounding the nucleus of pyramidal cell neurons was termed perikaryon. It contained mitochondria, cisternae of the rough endoplasmic reticulum, Golgi apparatus, free ribosomes and few lysosomes. Nissle granule was defined as a cluster of endoplasmic reticulum plus ribosomes pound to the outer surface of its cisternae. An axon-somatic synapse was observed containing both myelinated and non myelinated axons (Figure 1(A)).

\section{2) Treated Group}

\section{Electron Microscopic Findings:}

In the experimental treated group (B), ultrathin section of the frontal cortex of adult male rats showed that the pyramidal cell neurons had normal nucleus with mild aggregation of the chromatin, peripheral chromatin margination and peripheral nucleolus.

The perikaryon of the pyramidal cell neurons was variable. The cytoplasm contains degenerated mitochondria, fragmented rough endoplasmic reticulum, infiltration of ribosomes, and few cytoplasmic granules. An axo-somatic junction could be identified, non-myelinated axons appeared normal, and some of them appeared empty. Some of the myelinated axons appeared normal, another myelinated axon had irregular contour. Most of the myelinated axons had vacuolated myelin sheaths (Figure 1(B)).

\section{3) Recovery Group}

\section{Electron Microscopic Findings:}

In the recovery group (C), ultra-thin sections of the frontal cortex of the adult rats showed nearly complete recovery where the pyramidal cell neurons had normal nucleus and the perikaryon showed increase number of cell organelles and increased cisternae of rough endoplasmic reticulum and non-myelinated axons (Figure 1(C)).

\section{Discussion}

Sexual dysfunction was a serious medical and social problem in $10 \%-52 \%$ in men and $25 \%-63 \%$ in women [16]. Numerous central and peripheral neural circuits control sexual activity. Although several aspects of sexual motivation and performance were known, a complete picture of the various factors that 


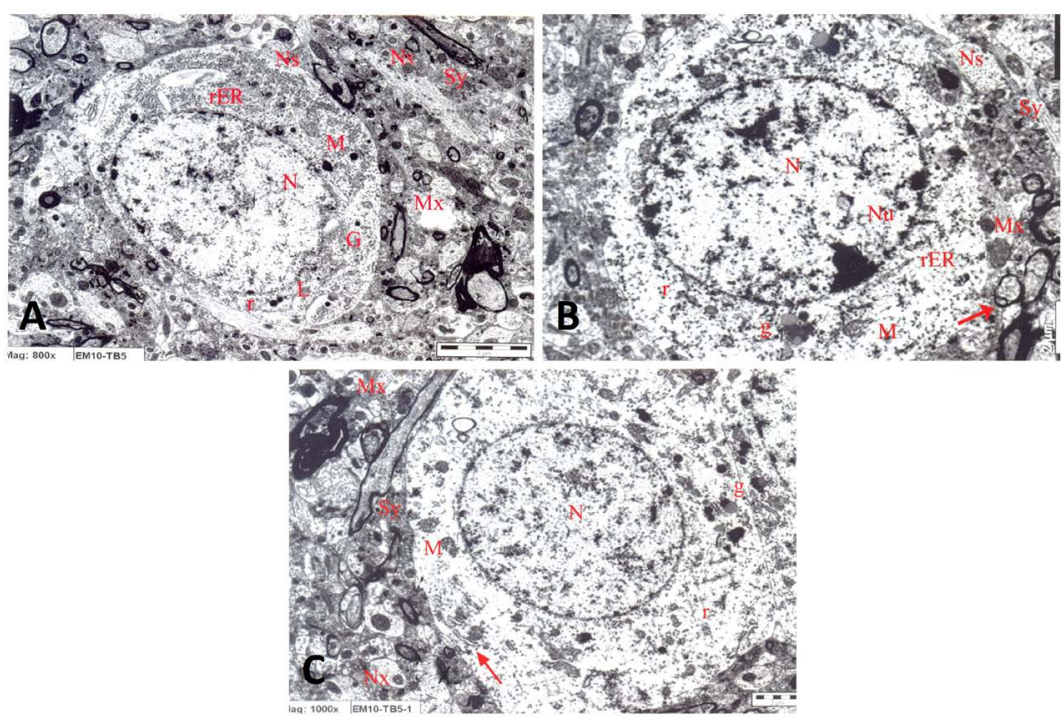

Figure 1. (A) Electro-micrograph of the pyramidal cell of the frontal cortex of control adult rat showing that the pyramidal cell has euchromatic nucleus $(\mathrm{N})$. The cell has normal cytoplasmic organelles, including mitochondria $(M)$, rough endoplasmic reticulum (rER), Golgi apparatus (G), free ribosomes (r), and lysosomes (L). Notice presence of Nissle granules (Ns). An axo-somatic synapse (Sy) is observed, containing mylinated axon $(\mathrm{Mx})$ and non-myelinated axon $(\mathrm{Nx})(\times 5000)$; (B) Electro-micrograph of the pyramidal cell of the frontal cortex of the experimentally treated rat with therapeutic dose of Sildenafil citrate showing the pyramidal cell where its nucleus $(\mathrm{N})$ is normal with euchromatic and peripheral nucleolus $(\mathrm{Nu})$. The cytoplasm contains degenerated mitochondria $(M)$, fragmented rough endoplasmic reticulum (rER), free ribosomes (r), and storage granules (g). Axosomatic synapse (Sy) shows myelinated axon (Mx) and non-myelinated axon $(\mathrm{Nx})$, with vaculation of the myelin sheath (arrow) of some myelinated axons $(\times 5000)$; (C) Electro-micrograph of the pyramidal cell of the frontal cortex of the recovery group showing the cytoplasm of the pyramidal cell neuron with signs of recovery in the form of increase number of normal cell organelles including; mitochondria $(M)$, ribosomes (r), large granules (g) and increased cisternae of rough endoplasmic reticulum (arrow). Axo-somatic synapse (Sy) contains normal myelinated axons $(\mathrm{Mx})$ and non-myelinated axons $(\mathrm{Nx})$. Notice normal nucleus $(\mathrm{N})(\times 5000)$.

control human sexual activity was still unknown. The available drug and treatment had limited efficacy and unpleasant side effects and controlled administration in certain disease condition [17]. Sildenafil citrate had been found to be effective and well tolerated in men with mild to moderate erectile dysfunction of no clinically identifiable organic cause [18]. It had been reported that sildenafil citrate significantly improved nocturnal penile erection in sildenafil nonresponding patients with psychogenic erectile dysfunction [19]. Several pharmacological and physiological properties of sildenafil had been described [20] [21] [22] So, the present study was conducted to evaluate the effect of chronic administration of sildenafil citrate in therapeutic dose on the ultra-structure of the pyramidal cell neurons of the frontal cortex in adult male rats.

The results of the present study revealed that administration of sildenafil citrate in therapeutic dose for 30 days to adult male rats induced varied degree of cellular degenerative changes in the cytoplasm of the pyramidal cell neuron of 
the frontal cortex. These degenerative changes were including degenerated mitochondria, focal fragmentation of the rough endoplasmic reticulum, large lysosomal bodies, and varying degree of ribosomal infiltration. In addition; many myelinated axons showed vaculation of their myelin sheaths.

In agreement with the results of the present study, Cunningham and Smith [23] reported neuropathy of the optic tract associated with chronic administration of viagra in human, which induced blindness. Monatero et al. [24] reported intra-cerebral hemorrhage associated with treatment by sildenafil citrate in human. Also, Pomeranz et al. [25] and Pomeranz and Bhavzsar [26] reported degenerative neuropathy of the optic nerve after use of sildenafil for treatment of erectile dysfunction in humans. Farooq et al. [27] reported that chronic administration of sildenafil citrate in human induced several neurological disorders including the medial geniculate body and frontal cortex.

In association with results of the present study, Eweka and Eweka [28] reported that chronic administration of sildenafil citrate in different doses for 30 days induced various degrees of cellular degenerative changes, cellular hypertrophy, and intracellular vacuolations in the superior colliculus in the adult Wister rats. Again, Eweka and Eweka [13] reported that chronic administration of sildenafil citrate for 30 days induced some decreased of cellular populations, degenerative changes, cellular hypertrophy, and some vacuolations appearing in the stroma in the medial geniculate body of adult Wister rats. These changes were more severe in the rats receiving higher dose of sildenafil citrate.

The cerebral effects of sildenafil citrate were due to increased risk of the detrimental effect on the cerebral blood flow (CBF) especially with patients with cerebro-vascular risk factors. There were two different pattern perfusion changes after administration of sildenafil citrate; 1) decrease of local or regional perfusion in one or more areas of the brain compared to baseline, and 2) a local decrease in one or more region combined with increased perfusion in other locations [29] The decrease of the post sildenafil perfusion might be related to abnormal reaction of dynamic cerebral auto regulation. The dynamic cerebral auto-regulation was defined as the ability to restore (CBF) in situations of sudden changed in perfusion pressure. The impairment was well documented unilaterally or bilaterally in acute stroke [30] and in the presence of intracranial or extra cranial artery stenosis [31]. This auto regulation was not impaired in elderly persons or in previously treated hypertensive patients [32].

In the recovery animals, ultra thin section revealed nearly complete recovery of the pyramidal cell neurons. In agreement with the results of the present study, Morgan et al. [33] and Saritz and Caplan [34] reported spontaneous recovery of patients suffering from transient ischemic attack after sildenafil citrate used, and patient suffering from transient global amnesia after sildenafil citrate use.

\section{Conflicts of Interest}

The author declares no conflicts of interest regarding the publication of this paper. 


\section{References}

[1] Wanda, M. and Cohn, G. (1991) Handbook of Toxicological Pathology. Academic Press, Sydney, New York, 625-674.

[2] Boolell, U.M., Alle, M., Ballard, G., Nayalor, A. and Gigll, C. (1996) Oral Sildenafil: An Orally Active Type GMPS for Treatment of Penile Erectile Dysfunction. International Journal of Impotence Research, 8, 47-52.

[3] Benchkroun, A., Faik, M. and Benjelloun, S. (2003) A Baseline-Controlled Open-Label Study to Assess the Safety and Efficacy of Sildenafil Citrate (Viagra) in Patients with Erectile Dysfunction. International Journal of Impotence Research, 1, 519-524. https://doi.org/10.1038/sj.ijir.3900969

[4] Wellis, R., Corbin, J., Francis, S. and Ellis, P. (1999) Tissue Distribution of Phosphodiesterese Families and the Effect of Sildenafil on Tissue in Vitro. American Journal of Cardiology, 83, 3c-12c. https://doi.org/10.1016/S0002-9149(99)00042-9

[5] Giorgi, M., Squitti, R., Bonsi, P. and Toschi, G. (1994) Activities of 3,5, Cyclic Nucleotide Phosphodiesterase in the Superior Cervical Ganglion in Rats. Neurochemistry International, 25, 493-500. https://doi.org/10.1016/0197-0186(94)90026-4

[6] Giordano, D., Desterani, M., Citro, G. and Giorgy, H. (2001) Expression of CGMP-Specific PDES in Mouse Tissue. Biochimica et Biophysica Acta, 1539, 16-27. https://doi.org/10.1016/S0167-4889(01)00086-6

[7] Basu, A. and Ryder, R. (2004) New Treatment Option for Erectile Dysfunction in Patients with D.M. Drug, 69, 2667-2688. https://doi.org/10.2165/00003495-200464230-00004

[8] Feldman, R.M., Meuleman, E. and Strees, W. (1999) Sildenafil Citrate in the Treatment of Erectile Dysfunction. International Journal of Clinical Practice, 53, 10-12.

[9] Deforge, D., Blakman, J. and Gamtty, C. (2006) Male Erectile Dysfunction Following Spinal Cord Injury. Spinal Cord, 44, 465-473. https://doi.org/10.1038/sj.sc.3101880

[10] Aviv, A., Shelef, A. and Weizeman, A. (2004) An Open-Label Trial of Sildenafil Treatment in Male Schizophrenia Patients with Erectile Dysfunction. Journal of Clinical Psychiatry, 65, 96-103. https://doi.org/10.4088/JCP.v65n0117

[11] Gopalakrishnan, R., Jakob, K. and Kuruvilla, A. (2006) Sildenafil in Treatment of Antipsychotic-Induced Erectile Dysfunction. American Journal of Psychiatry, 163, 494-499. https://doi.org/10.1176/appi.ajp.163.3.494

[12] FDA (2015) Viagra-Sildenafil Citrate Tablet, Film Coated: Full Prescribing Information. http://labeling.pfizer.com/ShowLabeling.aspx?id=652

[13] Eweka, A.O. and Eweka, A.B. (2011) The Effect of Sidenafil Citrate on the Medial Geneculate Body of Adult Rat. Journal of Cell and Animal Biology, 5, 56-60.

[14] Palay, S. and Chan-Palay, L. (1974) Technique of Electron Microscope. In: Cytology and Organization, Springer Verlag, Berlin, Chap. 8, 105-132.

[15] Hayat, N. (1986) Basic Technique for Transmission Electron Microscope. Academic Press, Cambridge, 1-20. https://doi.org/10.1016/B978-0-12-333926-3.50004-X

[16] Tharakan, B. and Banyaw, B. (2005) Potential Therapy in Sexual Dysfunction. Physical Therapy Research, 19, 457-463. https://doi.org/10.1002/ptr.1634

[17] McMahan, C., Samali, R. and Johson, H. (2000) Efficacy Safety and Patient Acceptance of Sildenafil Citrate as Treatment of Erectile Dysfunction. Journal of Urology, 164, 1192-1196. https://doi.org/10.1016/S0022-5347(05)67139-X

[18] Eardley, I. (2001) Efficacy and Safety of Seldenafil Citrate in the Treatment of Men with Erectile Dysfunction. The British Journal of Psychiatry, 178, 325-330. 
https://doi.org/10.1192/bjp.178.4.325

[19] Abdel-Naser, M., Iman, A. and Wollena, U. (2004) Sildenafil Citrate Significantly Improves Nocturnal Penile Erection in Sildenafil Nonresponding Patients with Psychogenic Erectile Dysfunction. International Journal of Impotence Research, 16, 552-556. https://doi.org/10.1038/sj.ijir.3901245

[20] Cheitlin, M., Hutter, A., Brindis, R., Gars, P. and Kaul, S. (1999) The Use of Sildanafil Citrate (Viagra) in Patients with Cardiovascular Disease. Circulation Journal, 99, 168-177. https://doi.org/10.1161/01.CIR.99.1.168

[21] Gali, N., Ghofrani, H., et al. (2005) Sidanafil Citrate Therapy for Pulmonary Arterial Hypertention. The New England Journal of Medicine, 353, 2148-2157. https://doi.org/10.1056/NEJMoa050010

[22] Hoeper, M., Welt, T., Izbicki and Rubin, L. (2006) Sidanafil Citrate Therapy for Pulmonary Arterial Hypertention. The New England Journal of Medicine, 354, 1019-1093. https://doi.org/10.1056/NEJMc053442

[23] Cunningham, A.V. and Smith, K.H. (2001) Anterior Ischemic Optic Neurobathy Associated with Viagra. Journal of Neuro-Ophthalmology, 21, 22-25. https://doi.org/10.1097/00041327-200103000-00006

[24] Pipia, M.R., Camardo, L. and Camardo, R. (2001) Intracranial Hemorrhage Associated with Sildenafil Citrate. Journal of Neurology, 248, 141-142. https://doi.org/10.1007/s004150170250

[25] Pomeranz, H., Smith, K., Hart, W. and Egan, R. (2002) Sildenafil-Associated Non-Arterial Anterior Ischemic Optic Neuropathy. Ophthalmology, 109, 584-587. https://doi.org/10.1016/S0161-6420(01)00976-9

[26] Pomeranz, H. and Bhavzsar, A. (2005) Non Arterial Ischemic Optic Neuropathy Is Developing Soon after Use of Sildenafil Citrate (Viagra). Journal of Neuro-Ophthalmology, 25, 9-13. https://doi.org/10.1097/00041327-200503000-00003

[27] Farooq, M., Naravetlo, B., Moor, P. and Gupta, R. (2008) Role of Sildenafil Citrate in Neurological Disorder. Clinical Neuropharmacology, 31, 535-562. https://doi.org/10.1097/WNF.0b013e31815cd94c

[28] Eweka, A.O. and Eweka, A.B. (2010) The Effect of Sidenafil Citrate on the Superior Colliculus of Adult Rat. Biology and Medicine, 2, 24-29.

[29] Lorberboyn, M., Mena, I., Wainnstem, J., Boes, M. and Laml, Y. (2009) Effect of Sildenafil Citrate (Viagra) on Cerebral Blood Flow in Patients with Cerebro-Vascular Risk Factors. Acta Neurologica Scandinavica, 121, 370-376. https://doi.org/10.1111/j.1600-0404.2009.01307.x

[30] Reinhard, M., Bolh, M.B. and Guschl bouer, B. (2005) Dynamic Cerebral Autoregulation in Acute Ischemic Stroke Assessed from Spontaneous Blood Pressure Fluctuation. Stroke, 36, 1691-1696. https://doi.org/10.1161/01.STR.0000173183.36331.ee

[31] Haubrich, C., Kruska, W., Diehl, R. and Kloetzsch, C. (2003) Dynamic Autoregulation Testing in Middle Cerebral Artery Stenosis. Stroke, 34, 1881-1885. https://doi.org/10.1161/01.STR.0000080936.36601.34

[32] Carey, B., Eames, P., Blake, M. and Potter, J. (2000) Dynamic Cerebral Autoregulation Is Unaffected by Aging. Stroke, 31, 2895-2900. https://doi.org/10.1161/01.STR.31.12.2895

[33] Morgan, J., Alhatou, M., Oberlies, J. and Johuston, K. (2001) Transient Ischemic Attack and Stroke Associated with Soildensafil Use. Neurology, 57, 1730-1731. https://doi.org/10.1212/WNL.57.9.1730

[34] Saritz, S. and Caplan, L. (2002) Transient Global Amnesia after Sildenafil Use. Neurology, 57, 778. https://doi.org/10.1212/WNL.59.5.778 